\title{
The ocular pulse and intraocular pressure as a screening test for carotid artery stenosis
}

\author{
EDWARD S PERKINS \\ From the Department of Ophthalmology, University of Iowa Hospitals and Clinics, USA
}

SUMMARY The ocular pulse and applanation tension were measured with a recording applanation tonometer in 38 patients suspected of having internal carotid artery stenosis. Abnormalities of the ocular pulse amplitude, intraocular pressure, or combinations of these two measurements were found in $23(82 \%)$ of 28 patients who were subsequently found to have angiographic evidence of $50 \%$ or more stenosis of one or both internal carotid arteries. Of 10 patients without angiographic evidence of carotid stenosis the ocular pulse amplitude, intraocular pressure, or both were abnormal in five, but two patients had an ocular cause for abnormality and two of the remaining three had evidence of carotid disease in the form of atheromatous plaques. These results suggest that measurement of the amplitude of the ocular pulse in addition to the intraocular pressure can predict the presence of carotid artery stenosis and indicate the need for further investigation. If a tonometer capable of measuring the pulse amplitude was used routinely in ophthalmic examinations, it would provide a useful screening test for the early diagnosis and treatment of carotid artery disease and might thereby reduce the frequency of strokes.

Carotid artery disease is an important cause of strokes, and, if the condition could be recognised before symptoms arise, surgical treatment might be effective in reducing the incidence of death and disability from strokes. It is not surprising, therefore, that many non-invasive screening tests for carotid disease have been devised to detect patients requiring angiography. Such tests, however, are applied only when the patient presents with symptoms suggestive of vascular insufficiency.

Most people over the age of 40 require glasses for near work and are likely to attend an ophthalmologist or optometrist at regular intervals for a refraction, so that a screening test which was part of a routine ophthalmic examination could be applied on a large scale with little extra effort or cost. One such test is the measurement of the ocular pulse and the comparison of the pulse amplitude in the two eyes. Ophthalmologists and many optometrists routinely measure the intraocular pressure as a screening test for glaucoma, and some tonometers can indicate the ocular pulse amplitude, though the value of this measurement is rarely recognised, and only the mean

Correspondence to Dr Edward S Perkins, C S O'Brien Library, Department of Ophthalmology, University of Iowa Hospitals and Clinics, Iowa City, Iowa 52242, USA. level of pressure is normally recorded. As the amplitude of the ocular pulse reflects the volume of blood entering the eye with each cardiac pulse wave, it is dependent in part on the integrity of the arterial supply to the eye, and stenosis of the internal carotid would be expected to result in a reduced ocular pulse amplitude, and perhaps a low intraocular pressure.

The purpose of this paper is to compare the ocular pulse amplitudes and intraocular pressure with the results of carotid angiography in a series of patients suspected of having carotid artery disease.

\section{Patients and methods}

\section{PATIENTS}

The patients were derived from the Vascular Clinic of the Department of Ophthalmology and the Cardiovascular Department of the University of Iowa Hospitals and Clinics. They were suspected of having carotid artery disease and had had angiography of the internal carotid arteries (ICA). The ocular pulse studies were performed and the records analysed before the angiography results were known.

TONOMETRY AND OCULAR PULSE RECORDING The ocular pulse amplitude was determined with a 
Goldmann applanation tonometer modified to give continuous recording of the intraocular pressure on a Hewlett-Packard heated stylus recorder. The Goldmann prism had a small chamber $2 \mathrm{~mm}$ in diameter drilled into the face of the prism, and the opening was covered with a very thin mylar membrane. The chamber was filled with water through lateral openings and connected by a short length of tubing to a pressure transducer. The fluorescein rings were adjusted in the normal manner and the prism centred so that the opening of the chamber lay within the applanated area. Under these conditions the intraocular pressure was transmitted through the cornea and the membrane to the fluid in the chamber and was recorded by the pressure transducer.'

CRITERIA OF ABNORMALITY OF THE OCULAR PULSE The ocular pulse results from the influx of blood into the eye with each cardiac cycle, and the amplitude of the pulse wave (i.e., the change in intraocular pressure from diastole to systole) will depend on the pulse pressure and the adequacy of the blood supply to the eye, the volume of the choroidal vascular bed, and the relation between volume changes and pressure changes in the individual eye. In normal eyes the latter factor is probably the most important cause of interindividual variations. If a similar volume of blood enters the eye of normal subjects the resulting pressure change will be greater in small hypermetropic eyes than in large myopic eyes. A low pulse amplitude can therefore be due to myopia, ${ }^{23}$ and the level below which the pulse amplitude is abnormal has to be modified with respect to the refraction.

Previous studies on a presumably normal population showed that a pulse amplitude of $1.5 \mathrm{mmHg}$ or less occurred in only three out of 82 patients with hypermetropia or emmetropia, and only two out of 27 myopes had amplitudes of less than $1 \mathrm{mmHg}$. The difference in pulse amplitude between the two eyes exceeded $0.5 \mathrm{mmHg}$ in only $2 \%$.

The criteria of an abnormal pulse based upon the above findings were: (1) a pulse amplitude of 1.5 $\mathrm{mmHg}$ or less for hypermetropic and emmetropic eyes; (2) a pulse amplitude of $1.0 \mathrm{mmHg}$ or less for myopic eyes ( $>-1.00 \mathrm{D}) ;(3)$ a difference between the pulse amplitudes of the two eyes of more than 0.5 mmHg.

In the same normal population an intraocular pressure of $10 \mathrm{mmHg}$ or less was found in only $7 \cdot 3 \%$ and a difference in pressure between the two eyes of $3.0 \mathrm{mmHg}$ occurred in only $2.75 \%$.

The criteria chosen for considering the intraocular pressure abnormal were: (1) an applanation reading of $10 \mathrm{mmHg}$ or less in one or both eyes; (2) a difference of $3.0 \mathrm{mmHg}$ or more between the two eyes.

\section{Results}

Thirty-eight patients who subsequently underwent carotid angiography were examined, and the results can be summarised as follows.

\section{CASES WITH ABNORMAL OCULAR PULSE}

AMPLITUDES (Table 1a)

There were 26 cases with a low ocular pulse amplitude and/or an intraocular difference in amplitude of more than $0.5 \mathrm{mmHg}$. Twenty-one of these cases $(81 \%)$ were found to have angiographic evidence of internal carotid artery stenosis in one or both arteries. Of the five cases with abnormal pulses but no stenosis three had atheromatous plaques in the internal carotid artery, including one patient (case 3 ) who had had an occlusion of the central retinal artery and one patient with amaurosis fugax (case 27). It is possible, therefore, that there was reduced flow in the arteries in these patients, though no stenosis was reported on angiography.

The two remaining cases with abnormal pulses but no stenosis consisted of one patient who was subsequently diagnosed as having low-tension glaucoma (case 14) and one patient with amaurosis fugax (case 41). Abnormally low pulse amplitudes are known to occur in some patients with low-tension glaucoma ${ }^{4}$ and this may be the reason for the false positive results in this case. The remaining case with abnormal pulses but no stenosis gave a history of amaurosis fugax, which suggests an intermittent reduction of blood supply to the eye in spite of normal angiography.

CASES WITH NORMAL PULSE AMPLITUDE BUT ABNORMAL OCULAR TENSIONS (Table 1b)

There were two patients in this group who were both found to have stenosis of one or both ICAs.

CASES WITH NORMAL OCULAR PULSE AMPLITUDES AND NORMAL TENSIONS (Table 2)

There were 10 cases in this group and angiography showed no stenosis in five cases but stenosis in the other five. In three of the latter five there was a difference of $0.5 \mathrm{mmHg}$ between the pulse amplitudes of the two eyes, but by the criteria used these must be included in the false negative rate of $50 \%$.

The results in terms of positive and negative findings related to the angiographic reports are summarised in Table 3.

\section{Discussion}

Ophthalmodynamometry, ophthalmoplethysmography, photoplethysmography, and Doppler flow studies have all been used as non-invasive tests for carotid artery disease, and the results of different 
Table 1a Cases with abnormal ocular pulse amplitudes

\begin{tabular}{|c|c|c|c|c|c|c|}
\hline $\begin{array}{l}\text { Case } \\
\text { no. }\end{array}$ & $\begin{array}{l}\text { Mean pulse } \\
\text { amplitude } \\
\mathrm{mmHg}\end{array}$ & $\begin{array}{l}\text { Difference } \\
\text { in amplitude } \\
\mathrm{mmHg}\end{array}$ & $\begin{array}{l}\text { Tensions } \\
\mathrm{mmHg}\end{array}$ & $\begin{array}{l}\text { Difference } \\
\text { in tensions }\end{array}$ & Angiographic findings & Other findings \\
\hline 3 & $\begin{array}{l}\text { OD } 1 \cdot 5 \\
\text { OS } 1 \cdot 5\end{array}$ & $0 \cdot 0$ & $\begin{array}{l}\text { OD } 26 \\
\text { OS } 17\end{array}$ & $9 \cdot 0$ & Carotid plaques but no stenosis & $\begin{array}{l}\text { OD central retinal artery occlusion, } \\
\text { doppler abnormal }\end{array}$ \\
\hline 5 & $\begin{array}{l}\text { OD } 0.5 \\
\text { OS } 0.7\end{array}$ & $0 \cdot 2$ & $\begin{array}{l}\text { OD } 18 \\
\text { OS } 21\end{array}$ & $3 \cdot 0$ & $\begin{array}{l}\text { Total occlusion R ICA } \\
\text { Almost total occlusion L ICA }\end{array}$ & \\
\hline 6 & $\begin{array}{l}\text { OD } 0.25 \\
\text { OS } 9 \cdot 5\end{array}$ & $0 \cdot 25$ & $\begin{array}{l}\text { not } \\
\text { recorded }\end{array}$ & & $\begin{array}{l}\text { Atheroma R ICA, no stenosis } \\
75 \% \text { stenosis L ICA }\end{array}$ & \\
\hline 7 & $\begin{array}{l}\text { OD }<0 \cdot 5 \\
\text { OS }<0 \cdot 5\end{array}$ & $0 \cdot 0$ & $\begin{array}{l}\text { OD } 11 \\
\text { OS } 11\end{array}$ & $0 \cdot 0$ & $\begin{array}{l}\text { Severe ulcerated plaques R ICA } \\
\text { Total occlusion L ICA }\end{array}$ & \\
\hline 8 & $\begin{array}{l}\text { OD }<0 \cdot 5 \\
\text { OS } 0 \cdot 0\end{array}$ & $0 \cdot 25$ & $\begin{array}{l}\text { OD } 9 \\
\text { OS } 10\end{array}$ & $1 \cdot 0$ & Complete occlusion both ICAs & \\
\hline 9 & $\begin{array}{l}\text { OD } 0.5 \\
\text { OS } 0.75\end{array}$ & $0 \cdot 25$ & $\begin{array}{l}\text { OD } 11 \\
\text { OS } 9\end{array}$ & $1 \cdot 0$ & Severe stenosis both ICAs & \\
\hline 12 & $\begin{array}{l}\text { OD } 2.25 \\
\text { OS } 1.25\end{array}$ & $1 \cdot 0$ & $\begin{array}{l}\text { OD } 10 \\
\text { OS } 6\end{array}$ & $4 \cdot 0$ & Total occlusion L ICA & \\
\hline 14 & $\begin{array}{l}\text { OD } 0.75 \\
\text { OS } 0.75\end{array}$ & $0 \cdot 0$ & $\begin{array}{l}\text { OD } 15 \\
\text { OS } 20\end{array}$ & $5 \cdot 0$ & $\begin{array}{l}\text { Minimal irregularity L ICA but } \\
\text { no stenosis }\end{array}$ & $\begin{array}{l}\text { History of amaurosis fugax; diagnosed } \\
\text { low tension glaucoma }\end{array}$ \\
\hline 17 & $\begin{array}{l}\text { OD } 0.75 \\
\text { OS } 1.5\end{array}$ & $0 \cdot 75$ & $\begin{array}{l}\text { OD } 28 \\
\text { OS } 12\end{array}$ & $16 \cdot 0$ & $\begin{array}{l}\text { Complete occlusion R ICA } \\
90 \% \text { occlusion L ICA }\end{array}$ & $\begin{array}{l}\text { Severe peripheral vascular disease; } \\
\text { central retinal artery occlusion OD }\end{array}$ \\
\hline 18 & $\begin{array}{l}\text { OD } 2.0 \\
\text { OS } 0.75\end{array}$ & $1 \cdot 25$ & $\begin{array}{l}\text { OD } 14 \\
\text { OS } 20\end{array}$ & $6 \cdot 0$ & Bilateral occlusion ICAs & \\
\hline 19 & $\begin{array}{l}\text { OD } 0.5 \\
\text { OS } 0.25\end{array}$ & $0 \cdot 25$ & $\begin{array}{l}\text { OD } 16 \\
\text { OS } 16\end{array}$ & $0 \cdot 0$ & $\begin{array}{l}\text { Minor irregularity R ICA } \\
\text { Complete occlusion L ICA }\end{array}$ & $\begin{array}{l}\text { Central retinal artery } \\
\text { occlusion OS }\end{array}$ \\
\hline 20 & $\begin{array}{l}\text { OD } 1.75 \\
\text { OS } 1.25\end{array}$ & $0 \cdot 25$ & $\begin{array}{l}\text { OD } 16 \\
\text { OS } 16\end{array}$ & $0 \cdot 0$ & $\begin{array}{l}\text { Partial occlusion R ICA } \\
\text { Complete occlusion L ICA }\end{array}$ & \\
\hline 21 & $\begin{array}{l}\text { OD } 0.75 \\
\text { OS } 0.75\end{array}$ & $0 \cdot 0$ & $\begin{array}{l}\text { OD } 11 \\
\text { OS } 8\end{array}$ & $3 \cdot 0$ & $\begin{array}{l}\text { Plaques R ICA } \\
\text { Narrowing L common carotid and } \\
\text { severe disease L ICA }\end{array}$ & \\
\hline 22 & $\begin{array}{l}\text { OD } 0.75 \\
\text { OS } 0.5\end{array}$ & $0 \cdot 25$ & $\begin{array}{l}\text { OD } 13 \\
\text { OS } 11\end{array}$ & $2 \cdot 0$ & Plaques both ICAs but no stenosis & \\
\hline 25 & $\begin{array}{l}\text { OD } 3 \cdot 5 \\
\text { OS } 2 \cdot 0\end{array}$ & $1 \cdot 5$ & $\begin{array}{l}\text { OD } 15 \\
\text { OS } 13\end{array}$ & $2 \cdot 0$ & Occlusion of L ICA & \\
\hline 26 & $\begin{array}{l}\text { OD } 2.25 \\
\text { OS } 1.25\end{array}$ & $1 \cdot 0$ & $\begin{array}{l}\text { OD } 9 \\
\text { OS } 9\end{array}$ & $0 \cdot 0$ & $\begin{array}{l}\text { Irregularity } \mathrm{R} \text { bifurcation } \\
95 \% \text { stenosis L ICA }\end{array}$ & \\
\hline 27 & $\begin{array}{l}\text { OD } 7 \cdot 5 \\
\text { OS } 6 \cdot 0\end{array}$ & $1 \cdot 5$ & $\begin{array}{l}\text { OD } 20 \\
\text { OS } 19\end{array}$ & $1 \cdot 0$ & $\begin{array}{l}\text { Ulcerated plaque } \mathrm{R} \text { carotid at junction } \\
\text { Ulcerated plaques L ICA }\end{array}$ & Amaurosis fugax OS \\
\hline 30 & $\begin{array}{l}\text { OD } 2 \cdot 0 \\
\text { OS } 4 \cdot 0\end{array}$ & $2 \cdot 0$ & $\begin{array}{l}\text { OD } 18 \\
\text { OS } 22\end{array}$ & $4 \cdot 0$ & $\begin{array}{l}90 \% \text { occlusion R ICA } \\
50 \% \text { occlusion L ICA }\end{array}$ & \\
\hline 31 & $\begin{array}{l}\text { OD } 3 \cdot 0 \\
\text { OS } 2 \cdot 25\end{array}$ & $0 \cdot 75$ & $\begin{array}{l}\text { OD } 12 \\
\text { OS } 10\end{array}$ & $2 \cdot 0$ & Total occlusion L ICA & \\
\hline 33 & $\begin{array}{l}\text { OD } 6 \cdot 5 \\
\text { OS } 4 \cdot 75\end{array}$ & $1 \cdot 75$ & $\begin{array}{l}\text { OD } 20 \\
\text { OS } 20\end{array}$ & 0.0 & $\begin{array}{l}\text { Minimal irregularity R ICA } \\
\text { Tight stenosis origin L ICA }\end{array}$ & Hollenhorst plaques OS \\
\hline 34 & $\begin{array}{l}\text { OD } 2 \cdot 0 \\
\text { OS } 3 \cdot 0\end{array}$ & $1 \cdot 0$ & $\begin{array}{l}\text { OD } 38 \\
\text { OS } 22\end{array}$ & $16 \cdot 0$ & Stenosis R ICA & Open-angle glaucoma \\
\hline 36 & $\begin{array}{l}\text { OD } 1.5 \\
\text { OS } 1.5\end{array}$ & $0 \cdot 0$ & $\begin{array}{l}\text { OD } 9 \\
\text { OS } 9\end{array}$ & $0 \cdot 0$ & Less than $50 \%$ stenosis both ICAs & \\
\hline 37 & $\begin{array}{l}\text { OD } 1.0 \\
\text { OS } 1.0\end{array}$ & $0 \cdot 0$ & $\begin{array}{l}\text { OD } 10 \\
\text { OS } 10\end{array}$ & $0 \cdot 0$ & $\begin{array}{l}\text { No report R ICA } \\
90 \% \text { stenosis L ICA }\end{array}$ & \\
\hline 39 & $\begin{array}{l}\text { OD } 4 \cdot 0 \\
\text { OS } 5 \cdot 5\end{array}$ & $1 \cdot 5$ & $\begin{array}{l}\text { Not } \\
\text { recorded }\end{array}$ & & $\begin{array}{l}\text { Plaque } \mathrm{R} \text { common carotid. } \\
\text { Total occlusion } \\
\text { R ICA on repeat angiography }\end{array}$ & \\
\hline 41 & $\begin{array}{l}\text { OD } 3 \cdot 5 \\
\text { OS } 4 \cdot 5\end{array}$ & $1 \cdot 0$ & $\begin{array}{l}\text { OD } 14 \\
\text { OS } 14\end{array}$ & 0.0 & No evidence $R$ carotid disease & Amaurosis fugax $\mathrm{OD}$ \\
\hline 42 & $\begin{array}{l}\text { OD } 5 \cdot 0 \\
\text { OS } 3 \cdot 0\end{array}$ & $2 \cdot 0$ & $\begin{array}{l}\text { OD } 18 \\
\text { OS } 12\end{array}$ & $6 \cdot 0$ & $\begin{array}{l}\text { No report } R \\
\text { Total occlusion L ICA }\end{array}$ & \\
\hline
\end{tabular}


Table 1b Cases with normal pulse amplitudes but abnormal tensions

\begin{tabular}{lllllll}
\hline $\begin{array}{l}\text { Case } \\
\text { no. }\end{array}$ & $\begin{array}{l}\text { Mean pulse } \\
\text { amplitude } \\
m m H g\end{array}$ & $\begin{array}{l}\text { Difference } \\
\text { in amplitude } \\
m m H g\end{array}$ & $\begin{array}{l}\text { Tensions } \\
m m H g\end{array}$ & $\begin{array}{l}\text { Difference } \\
\text { in tensions }\end{array}$ & Angiographic findings & Other findings \\
\hline 1 & OD 2.5 & 0.25 & $\begin{array}{l}\text { OD 7.0 } \\
\text { OS 5.0 }\end{array}$ & 2.0 & $\begin{array}{l}\text { R ICA within normal } \\
\text { L ICA occlusion } \\
90 \%\end{array}$ & Venous stasis retinopathy OS \\
32 & $\begin{array}{l}\text { OS } 2.25 \\
\text { OD } 3.5\end{array}$ & 0.25 & OD 12 & & \\
OS 4.0 & 0.5 & OS 16 & 4.0 & $100 \%$ stenosis L ICA & \\
\hline
\end{tabular}

tests have been reviewed by many authors. ${ }^{5-7}$ All these methods require special apparatus and do not form part of a routine ophthalmic examination. They are all capable of correctly diagnosing carotid artery occlusion (particularly if it is unilateral) in a high percentage of cases.

The results of the present study suggest that abnormalities of the ocular pulse and intraocular pressure have a diagnostic value similar to that of other non-invasive tests. Eighty-two percent of cases were correctly diagnosed as having stenosis of one or both ICAs, and these results confirm and amplify previous studies on the ocular pulse.$^{8-10}$ False positive results were found in five out of 10 patients without angiographic evidence of stenosis of the internal carotid, but two patients had ocular disease to account for the abnormal ocular pulse and two of the remaining three patients had angiographic evidence of severe atheromatous disease of the ICA and could therefore be considered as true positive results.
However, a further patient with atheromatous disease of the carotids had normal pulse amplitudes and applanation tensions.

The degree of stenosis of the ICA which is reflected in an abnormal ocular pulse cannot be assessed exactly from the present series, as the stenosis was not always quantified in the angiography report. All the patients described as having 75 to $100 \%$ occlusion were correctly diagnosed. In three patients with normal ocular pulses the angiographic findings were described as 'occlusion,' 'focal stenosis,' and '50 to $60 \%$ stenosis' respectively. It is probably necessary to have at least $50 \%$ stenosis to reduce the ocular pulse significantly, a figure which agrees with experimental findings."

The criteria used for abnormality of the ocular pulse were a difference of more than $0.5 \mathrm{mmHg}$ between the two eyes and/or a pulse amplitude less than $1.5 \mathrm{mmHg}$ for hypermetropes and emmetropes, and $1.0 \mathrm{mmHg}$ for myopes. A difference in pulse

Table 2 Cases with normal ocular pulses and normal tension

\begin{tabular}{|c|c|c|c|c|c|c|}
\hline $\begin{array}{l}\text { Case } \\
\text { no. }\end{array}$ & $\begin{array}{l}\text { Mean pulse } \\
\text { amplitude } \\
\mathrm{mmHg}\end{array}$ & $\begin{array}{l}\text { Difference } \\
\text { in amplitude } \\
\mathrm{mmHg}\end{array}$ & $\begin{array}{l}\text { Tensions } \\
\text { mmHg }\end{array}$ & $\begin{array}{l}\text { Difference } \\
\text { in tensions }\end{array}$ & Angiographic findings & Other findings \\
\hline 2 & $\begin{array}{l}\text { OD } 2 \cdot 0 \\
\text { OS } 2 \cdot 25\end{array}$ & $0 \cdot 25$ & $\begin{array}{l}\text { OD } 12 \\
\text { OS } 12\end{array}$ & 0.0 & $\begin{array}{l}\text { Focal stenosis R ICA } \\
\text { No stenosis L ICA }\end{array}$ & \\
\hline 4 & $\begin{array}{l}\text { OD } 2 \cdot 5 \\
\text { OS } 2 \cdot 5\end{array}$ & $0 \cdot 0$ & $\begin{array}{l}\text { OD } 15 \\
\text { OS } 15\end{array}$ & $0 \cdot 0$ & $\begin{array}{l}\text { Ulcerated plaques both ICAs; } \\
\text { no stenosis }\end{array}$ & \\
\hline 10 & $\begin{array}{l}\text { OD } 3.0 \\
\text { OS } 3.0\end{array}$ & $0 \cdot 0$ & $\begin{array}{l}\text { OD } 20 \\
\text { OS } 20\end{array}$ & $0 \cdot 0$ & 50 to $60 \%$ stenosis R ICA & \\
\hline 13 & $\begin{array}{l}\text { OD } 3.0 \\
\text { OS } 3.0\end{array}$ & $0 \cdot 0$ & $\begin{array}{l}\text { OD } 18 \\
\text { OS } 18\end{array}$ & $0 \cdot 0$ & $\begin{array}{l}\text { Internal fold R ICA, no stenosis; } \\
\text { plaques L ICA, no stenosis }\end{array}$ & \\
\hline 15 & $\begin{array}{l}\text { OD } 3.0 \\
\text { OS } 3.5\end{array}$ & $0 \cdot 5$ & $\begin{array}{l}\text { OD } 15 \\
\text { OS } 13\end{array}$ & $2 \cdot 0$ & $\begin{array}{l}\text { Plaques bifurcation and R ICA; } \\
\text { extensive plaques L ICA }\end{array}$ & \\
\hline 23 & $\begin{array}{l}\text { OD } 3.5 \\
\text { OS } 3.0\end{array}$ & 0.5 & $\begin{array}{l}\text { OD } 14 \\
\text { OS } 14\end{array}$ & $0 \cdot 0$ & $\begin{array}{l}\text { Plaques both carotids but no } \\
\text { stenosis }\end{array}$ & Cerebral infarcts \\
\hline 24 & $\begin{array}{l}\text { OD } 2.0 \\
\text { OS } 2.5\end{array}$ & $0 \cdot 5$ & $\begin{array}{l}\text { OD } 14 \\
\text { OS } 14\end{array}$ & $0 \cdot 0$ & $\begin{array}{l}\text { Total occlusion R ICA; } \\
\text { atheroma carotid syphon } \mathrm{L}\end{array}$ & \\
\hline 28 & $\begin{array}{l}\text { OD } 4.5 \\
\text { OS } 4 \cdot 0\end{array}$ & 0.5 & $\begin{array}{l}\text { OD } 18 \\
\text { OS } 16\end{array}$ & $2 \cdot \dot{0}$ & $\begin{array}{l}\text { Stenotic area } R \text { ICA; } \\
\text { significant stenosis L ICA }\end{array}$ & \\
\hline 29 & $\begin{array}{l}\text { OD } 2 \cdot 25 \\
\text { OS } 2 \cdot 0\end{array}$ & 0.25 & $\begin{array}{l}\text { OD } 14 \\
\text { OS } 14\end{array}$ & $0 \cdot 0$ & No stenosis ICAs & Branch artery occlusion OS \\
\hline 40 & $\begin{array}{l}\text { OD } 5 \cdot 2 \\
\text { OS } 4 \cdot 7\end{array}$ & 0.5 & $\begin{array}{l}\text { OD } 14 \\
\text { OS } 14\end{array}$ & $0 \cdot 0$ & Complete occlusion L ICA & \\
\hline
\end{tabular}


Table 3 Summary of results in 38 patients

\begin{tabular}{lll}
\hline & No. of cases & Percent \\
\hline Carotid stenosis correctly diagnosed & 23 & $82 \cdot 14$ \\
False negatives & 5 & $17 \cdot 86$ \\
No stenosis correctly diagnosed & 5 & $50 \cdot 0$ \\
False positives & $5^{*}$ & $50 \cdot 0$ \\
\hline
\end{tabular}

*Two patients had ocular causes for abnormality.

amplitude of $0.5 \mathrm{mmHg}$ is suggestive of carotid artery disease but was found in $14 \%$ of an apparently normal population, ${ }^{2}$ and this criterion is likely to lead to more false positive results than an abnormally low amplitude.

In the absence of ocular disease or high myopia an ocular pulse amplitude less than $1.5 \mathrm{mmHg}$ or a difference of more than $0.5 \mathrm{mmHg}$ between the two eyes and/or applanation reading of $10 \mathrm{mmHg}$ or less is an indication of carotid artery disease and warrants further investigation.

The importance of these findings is not simply that the ocular pulse provides another non-invasive test of carotid artery blood flow but that measurement of the ocular pulse could be applied with tonometry as a presymptomatic screening method during a routine ophthalmic examination in the same way as tonometry is used as a screening method for glaucoma. It does demand, however, that the tonometer used is capable of measuring the amplitude of the ocular pulse. Apart from the instrument used in this study (which is not in production), there is only one type of instrument specifically designed to provide a recording of the ocular pulse. The Applanation Pneumotonograph (Alcon Surgical) and the Model $30 \mathrm{R} / \mathrm{T}$ Pneuma-Tonometer Tonographer (Digilab) both have facilities for recording the ocular pulse. The latter manufacturer also produces an oculocerebrovasculometer which includes a suction cup, so that the ocular pulse can be measured at various intraocular pressures." Any recording Schiøtz-type indentation tonometer can also be used to detect differences in pulse amplitudes between the two eyes, but the absolute value of pulse amplitude is more susceptible to errors induced by the weight of the instrument and the indentation of the plunger, which combine to raise the intraocular pressure of the eye being measured.

Applanation tonometry with the Goldmann prism is widely accepted as the standard of reference for tonometry and combines ease of use with high accuracy. Unfortunately it does not produce a record- ing of the pressure or ocular pulse, and the modification used in the present study was developed for this reason. It is possible to estimate the pulse amplitude by setting the semicircles of fluorescein so that they coincide first at their maximum excursion and then at their minimum excursion and noting the reading on the drum at each position. This method is less reliable than measurement from a recording, as the drum is

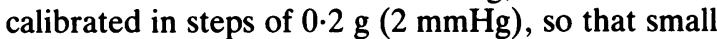
differences are difficult to measure accurately.

Carotid stenosis is a serious condition and is amenable to surgical treatment, so that it is a suitable candidate for presymptomatic detection if suitable screening methods were widely available. The measurement of the ocular pulse by tonometry would seem to offer a screening method easily applied during a routine ophthalmic examination. The ideal instrument for this would be an applanation tonometer with a recording system or an electrical output which could drive a small microprocessor with a visual display which could present the mean pressure and average a number of pulses to give a mean pulse amplitude.

I thank the staff of the Cardiovascular Department of the University of Iowa Hospitals and Clinics for referring patients. This work was financed by NIH grant no. EY-1151.

\section{References}

1 Perkins ES, Edwards J, Saxena RC. A new recording tonometer. Trans Ophthalmol Soc UK 1977; 97: 679-82.

2 Perkins ES. The ocular pulse. Curr Eye Res 1981; 1: 19-23.

3 To'mey KF, Faris BM, Jalkh AE, et al. Ocular pulse in high myopia. Ann Ophthalmol 1981; 13: 569-71.

4 Perkins ES, Phelps CD. The ocular pulse in low tension glaucoma. Klin Monatsbl Augenklkd 1984; 184: 303-4.

5 Bienfang DC. Carotid artery flow testing. In: Lessell S, Van Dolen JTW, eds. Neuroophthalmology. Amsterdam: Excerpta medica, 1980: 328-39.

6 Bone GE, Dickinson D, Pornajzl MJ. A prospective evaluation of indirect methods for detecting carotid atherosclerosis. Surg Gynecol Obstet 1981; 152: 587-92.

7 Baker JD, Kaufman M, Machleder H. Evaluation of internal carotid stenosis with the Chronopulse, an automated ocular pulse arrival time recorder. Am J Surg 1981; 142: 212-5.

$8 \mathrm{Knox}$ DL. Ocular pressure studies in the diagnosis of carotid artery disease. Trans Am Ophthalmol Soc 1973; 71: 459-87.

9 Hammerstein W. Rehorn W, Bischof G, et al. Tonography in arterial stenosis. Klin Monatsbl Augenklkd 1981; 179: 97-9.

10 Langham ME, To'mey KF, Drezion TJ. Carotid occlusive disease: effect of complete occlusion of internal carotid artery on intraocular pulse/pressure relation and on ophthalmic arterial pressure. Stroke 1981; 12: 759-65.

11 Zuckerman JL, Taylor KD, Grossman HJ. Noncontact detection of ocular pulse-correlation with carotid stenosis. Invest Ophthalmol Vis Sci 1977; 16: 1018-24. 